\title{
Determination of Elements Leachability from Sarcheshmeh Porphyry Copper Mine Tailings: Application of Toxicity Characteristic Leaching Procedure
}

\author{
Mehdi Khorasanipour • Afsar Eslami
}

Received: 7 May 2014 / Accepted: 1 August 2014 / Published online: 15 August 2014

(C) Springer International Publishing Switzerland 2014

\begin{abstract}
The Toxicity Characteristic Leaching Procedure (TCLP) was applied in order to determine the leachability and mobility of different trace metals and metalloids from the Sarcheshemh $\mathrm{Cu}$ mine tailings. Twenty one solid samples were collected from weathered and fresh tailings and also from evaporative secondary minerals and efflorescence salts associated with the oxidation zone of dried tailings. According to the TCLP results, the most leachable and mobile trace elements are $\mathrm{Ag}, \mathrm{Al}, \mathrm{Cd}, \mathrm{Ni}, \mathrm{S}, \mathrm{Se}, \mathrm{Co}, \mathrm{Cr}, \mathrm{Cu}, \mathrm{Fe}, \mathrm{Mn}$ and $\mathrm{Zn}$. These contaminant elements were concentrated in the surface evaporative layer formed on the top of old weathered tailings. Very high concentrations of $\mathrm{Al}\left(27,600 \mathrm{mgL}^{-1}\right), \mathrm{Cu}(56,900$ $\left.\mathrm{mgL}^{-1}\right), \mathrm{Mn}\left(13,260 \mathrm{mgL}^{-1}\right), \mathrm{S}\left(151,800 \mathrm{mgL}^{-1}\right)$, and $\mathrm{Zn}\left(3,935 \mathrm{mgL}^{-1}\right)$ were observed in the TCLP results of the evaporative samples (mean values are presented). The results obtained from evaporative and efflorescence samples were higher than the regulatory levels for $\mathrm{Al}, \mathrm{Cu}$, $\mathrm{Cd}, \mathrm{Ni}, \mathrm{Se}$, and $\mathrm{Zn}$. The maximum leachability was found for $\mathrm{Al}$ and $\mathrm{Cu}$, followed by $\mathrm{Ni}, \mathrm{Cd}$, $\mathrm{Zn}$, and Se. The results of this study are useful for the prediction of contamination potential of trace elements and environmental management of mine tailings.
\end{abstract}

Keywords Sarcheshmeh mine tailings · TCLP experiment · Trace elements · Semiarid climate

\section{Introduction}

Mobility of toxic trace elements is an important factor for evaluating the short and long-term environmental impacts associated with the different mine wastes (Khorasanipour et al. 2011). During the recent decades, many single and sequential extraction methods have been developed in order to evaluate mobility, bio-availability, and speciation of hazardous trace elements in soil, sediment and solid wastes (Filgueiras et al. 2002; Gleyzes et al. 2002; Hlavay et al. 2004). Among these extraction methods, the Toxicity Characteristic Leaching Procedure

M. Khorasanipour $(\bowtie)$

Faculty of Sciences, Department of Geology, Shahid Bahonar University of Kerman, Kerman- Pajohesh square, 76135-133 Kerman, Iran

e-mail: khorasani@uk.ac.ir

A. Eslami

Research and Development Division, Sarcheshmeh Copper Complex, Kerman, Iran 
(TCLP) was designed by the US EPA $(1986 ; 1994)$ in order to ascertain the leachability potential of hazardous and toxic chemicals from solid waste under typical environmental conditions (Chang et al. 2001; US EPA 1994; Halim et al. 2005).

Sulfidic mine tailings are usually classified as potential hazardous waste. They are produced during the flotation of sulfide ores such as $\mathrm{Cu}$ porphyry or mixed sulfide ores and consist mainly of pyrite and other gangue minerals (Lottermoser 2003; Khorasanipour et al. 2011; Khorasanipour and Eslami 2014). The disposal of tailings and their subsequent hydrogeochemical changes are one of the great environmental problems of the scientific community (McGregor and Blowes 2002; Sima et al. 2011; Grangeia et al. 2011). Environmental aspects of mine tailings wastes were also investigated by several authors (e.g., Dold and Fontboté 2001; Saxena and Dhimole 2006; Blowes et al. 1991; Coggans et al. 1999). According to these studies, if sulfide mine wastes such as tailings are exposed to the atmospheric oxygen or dissolved oxygen in the vadose zone, the oxidation of sulfide minerals will occur with the combination of several processes such as acid producing, acid buffering reactions and secondary mineral formation. During the weathering and oxidation reactions of tailings many site specific conditions such as the primary mineralogy of the tailings, the efficiency of recovery processes and climatic conditions profoundly affect the geochemical behavior of trace metals (Dold and Fontboté 2001; Lottermoser 2003; Berger et al. 2008).

The environmental impacts of mine tailings in arid and semiarid climate conditions are enormous due to the continuous water and/or wind erosions (Redwan and Rammlmair 2012). Climate variations provide fundamental controls on many reactions, such as weathering intensity, secondary mineral formation, and the mobility of contaminant metals and metalloids from tailings (Berger et al. 2008; Dold and Fontboté 2001; Khorasanipour and Eslami 2014). In arid and semiarid areas, evaporative concentration causes secondary mineral precipitation at the surface or at a particular depth of tailings dams. These sulfate precipitates are commonly referred to as "efflorescences" or "evaporative salts". Annual formation and dissolution of highly soluble sulfate salts can profoundly affect the hydro-geochemical of mine tailings (Olyphant et al. 1991; Bayless and Olyphant 1993; Hammarstrom et al. 2005).

The main object of this study is to identify the enrichment pattern of potentially hazardous trace elements including metals and metalloids in the Sarcheshmeh mine tailings. For this purpose, the TCL procedure was applied to the various solid samples including: fresh and weathered tailings, and secondary evaporative and efflorescence samples. These data are interesting and useful for prediction of contamination potential of tailings, because most of environmental concerns associated with these wastes are site specific and may vary from site to site considerably (Dold and Fontboté 2001; Lottermoser 2003; Akcil and Koldas 2006). Application of TCL procedure on the Sarcheshmeh mine tailings, as one of the world's largest porphyry copper deposits located in semiarid climate conditions, is notable and exciting.

\section{Site Description}

The Sarcheshmeh mine, in one of the largest Oligo-Miocene porphyry copper deposits in the world, is located in the central Iranian volcano-plutonic copper belt, $160 \mathrm{~km}$ southwest of Kerman, Iran (Fig. 1a). Mineralization at the Sarcheshmeh copper deposits is occurring as many zones of stockwork and vein types that are equally distributed between Eocene volcanics and Oligo-Miocene of quartz diorite, quartz monzonite and granodiorite composition (Atapour and Aftabi 2007). 


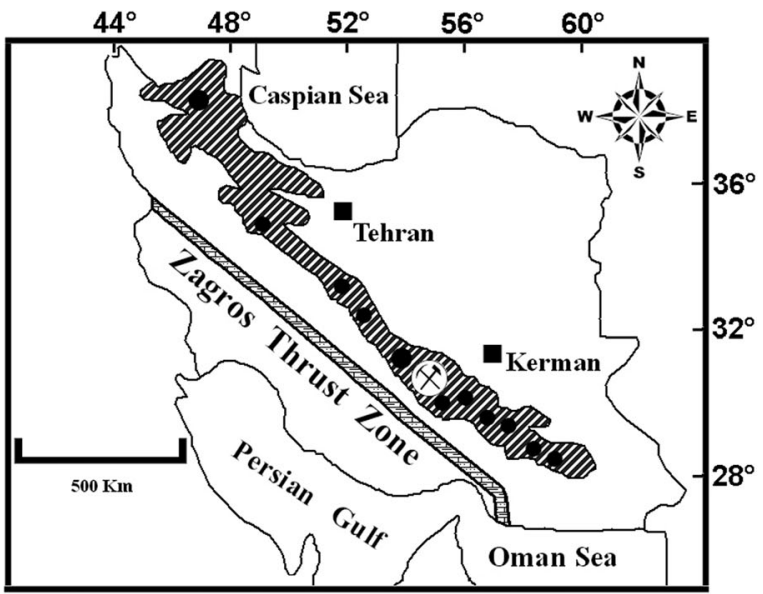

Central Iranian Volcano-plutonic Copper Belt

- Porphyry copper mineralization

(X) Sarcheshmeh porphyry copper mine
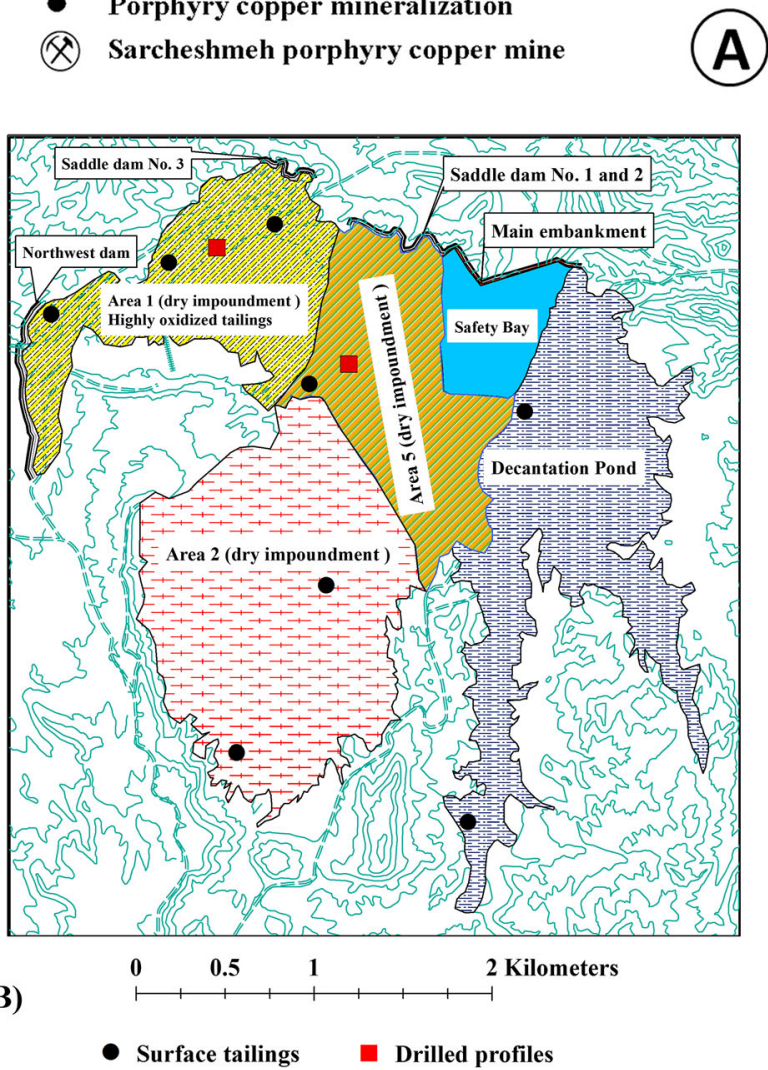

Fig. 1 a Central Iranian tectono-volcanic copper belt and the location of the Sarcheshmeh porphyry copper deposit (Modified after Shahabpour and Kramers 1987). b The main compartments of the Sarcheshmeh tailings sedimentation impoundment 
The Sarcheshmeh area is located in semiarid climate conditions. The annual temperature of this area ranges from -20 to $32{ }^{\circ} \mathrm{C}$, mean rainfall of $440 \mathrm{~mm}$, and annual evaporation of about $1,170 \mathrm{~mm}$ (Khorasanipour et al. 2011). The main lithological structures around the Sarcheshmeh porphyry copper mine are Eocene basic-to-intermediate volcanic rocks (trachybasalt, trachyandesite, and/or andesite) (Dimitrijevic 1973; Atapour and Aftabi 2007).

The production of mine tailings in the Sarcheshmeh concentration plants is nearly $1,215,000$ t per year (Khorasanipour et al. 2011). The mean content of pyrite as a main sulfide mineral is about $7.5 \%$ in the Sarchshmeh mine tailings (Khorasanipour et al. 2011).

The tailings sedimentation impoundment of the Sarcheshmeh copper mine is located in a mountainous area, approximately $19 \mathrm{~km}$ north of the mine. The dam, which currently consists of several ponds, has been operating as a cross valley type since 1976, and has been filled gradually and sequentially (Khorasanipour and Eslami 2014). The annual output of roughly 11.4 million $\mathrm{m}^{3}$ of tailings with specific gravity of $1.28 \mathrm{t} / \mathrm{m}^{3}$ was used as a basis for prediction of tailings dam volume. Figure $1 \mathrm{~b}$ shows the main compartments of the Sarcheshmenh dammed tailings pond. At present, the maximum depth of tailings reaches about $75 \mathrm{~m}$.

Most of the supernatant water from the decantation pond discharges into the safety bay and is then recycled to the Sarcheshmeh copper complex for further industrial use. Semiarid climate conditions and high evaporation rate are other significant factors that cause most of tailing impoundments to dry quickly. Field indications of the weathering reactions, including oxidation of sulfide minerals contained within the tailings and massive precipitation of secondary evaporative minerals are well observed in the oxidation zone of dried compartments of the Sarcheshmeh tailings impoundment. Some of the field indications of tailings weathering are presented in Fig. $2 \mathrm{a}$ and $\mathrm{b}$.

\section{Material and Methods}

Twenty one solid samples were collected mainly from weathered and fresh tailings and also from evaporative secondary minerals and efflorescence salts associated with the oxidation zone of dry impoundments. Figure 3 shows the schematic representation of data acquisition. Samples were collected by plastic device and stored in air-tight plastic bags. After oven drying and microwave multi-acid digestion $\left(\mathrm{HCl}+\mathrm{HNO}_{3}+\mathrm{HF}+\right.$ boric acid solution), the total content of target trace elements were determined using ICP-MS (As, $\mathrm{Cd}, \mathrm{Co}, \mathrm{Cu}, \mathrm{Mo}, \mathrm{Ni}, \mathrm{Pb}, \mathrm{Sb}, \mathrm{Se}, \mathrm{Sn}$, and $\mathrm{Zn}$ ) and ICP-OES (Fe, Mn, Cr, and S) at the Labwest Laboratory, Perth, Australia.

\subsection{Leaching Procedure}

In this study, the US EPA TCLP (1994) was applied using one out of two different buffer acidic leaching solutions depending on the alkalinity and the buffering capacity of waste samples. These extraction solutions are "solution 1" with a $\mathrm{pH}$ of $4.93 \pm 0.05$ and "solution 2" with a pH of $2.99 \pm 0.05$ (Margui et al. 2004). The initial $\mathrm{pH}$ of samples is a key factor for the selection of the appropriate leaching solution which is determined by the addition of $96.5 \mathrm{~mL}$ of deionized water to $5 \mathrm{~g}$ of each solid phase into borosilicate glass beaker. The beaker was covered with a watch glass and stirred vigorously for 5 min using a magnetic stirrer and then the $\mathrm{pH}$ of the solution was recorded using Toledo MP$120 \mathrm{pH}$ meter model. The $\mathrm{pH}$ values of the samples range from 2.85 to 8.31 (Table 1). 

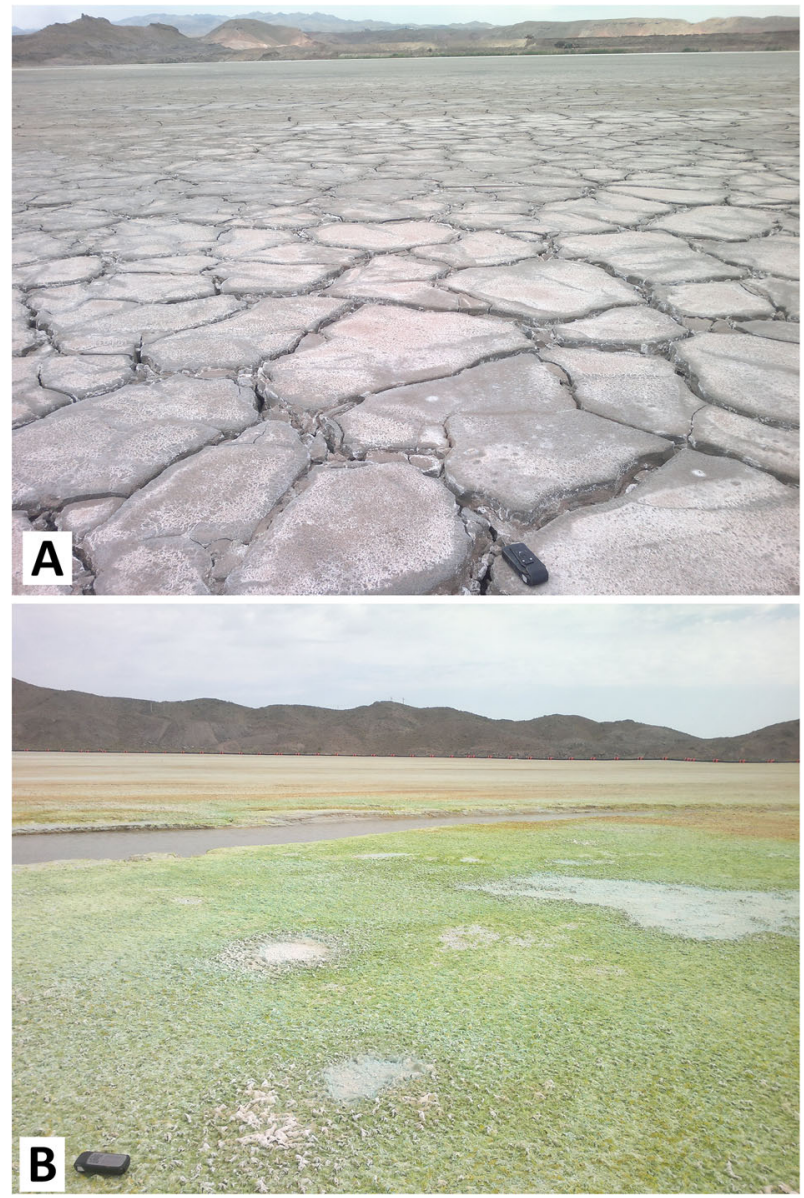

Fig. 2 a Dried fresh tailings due to the high evaporation rate and reuse of tailings water. $\mathbf{b}$ Massive precipitations of secondary evaporative minerals and efflorescence salts formed on the top of old weathered tailings

The acidic $\mathrm{pH}$ values were mainly associated with the weathered tailings and secondary evaporative phases. Based on the initial $\mathrm{pH}$ values, the extraction "solution 1" was used for all samples as specified by the US EPA (1994). This extraction solution is prepared by adding $5.7 \mathrm{~mL}$ of glacial acetic acid and $64.3 \mathrm{~mL}$ of $1 \mathrm{~N} \mathrm{NaOH}$ to $500 \mathrm{~mL}$ of reagent water and then diluted to a volume of 1 liter.

TCLP involves leaching at ambient conditions and Liquid to Solid (L/S) ratio equal to $20 \mathrm{~L} /$ $\mathrm{kg}$ for $18 \pm 2 \mathrm{~h}$. It is assumed that steady-state conditions were met after this period. Following the extraction period the liquid extracts were separated from the solid phase by centrifugation at 3,500 rpm, and then filtration through $0.45 \mu \mathrm{m}$ filter (ALBET, NitratoCelulosa, model). All extracts were acidified using nitric acid to $\mathrm{pH}<2$ and analyzed using ICP-MS/OES at the Labwest Laboratory, Pert, Australia. The limit of detection for target trace elements mostly ranges from 0.5 to $1 \mu \mathrm{g} / \mathrm{L}$.

Quality assurance of the leaching procedure was achieved using analysis of method blank (containing the extraction solution but no solid phase) and also carrying out the leaching procedure in duplicate for a number of samples. The Relative Percent of Difference (RPD) of the results obtained from repeated samples was calculated using following Eq. (1). The RPD is 


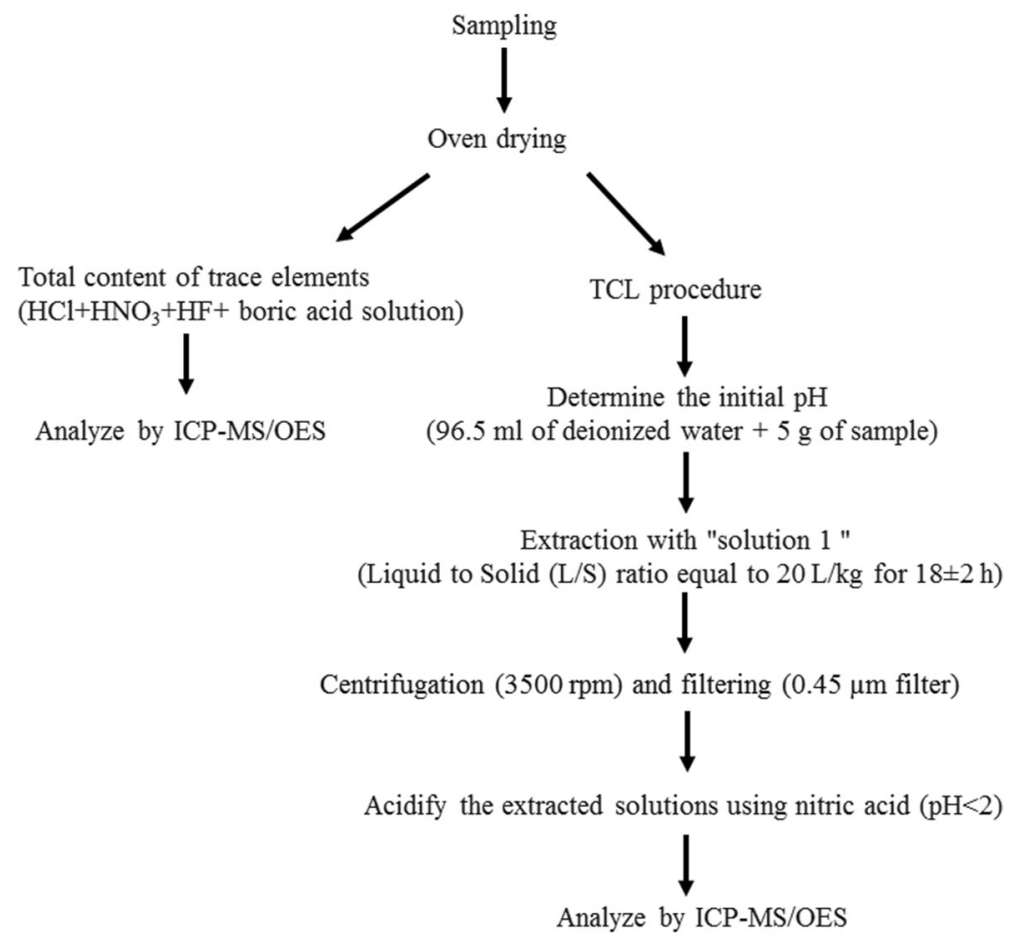

Fig. 3 Schematic representation of data acquisition

the difference between duplicate values divided by the average of the duplicate values and multiplied by 100 .

$$
\mathrm{RPD}=\frac{(\mathrm{A}-\mathrm{B})}{(\mathrm{A}+\mathrm{B}) / 2} \times 100
$$

The RPD values for target elements are mainly below $\pm 2 \%$. The accuracy and precision of results, as proposed by Zhang (2007), were verified by analyzing multi-elemental reference materials and duplicating same solutions, respectively.

\subsection{Statistical Methods}

The multivariate relationships between elements (or variables) were investigated by using of principal components analysis (PCA), and cluster analysis (CA) methods. In order to correct the magnitude and scale differences, the varimax normalized rotation PCA was performed on the data sets using correlation matrix (DelValls et al. 1998; Emmerson et al. 1997; Webster 2001). Significant principal components (eigenvalues $>1.0$ ) were extracted from the variables based on the Kaiser Criterion (Kaiser 1960). The factor loadings were considered significant or excellent if they were $>0.6$ or $>0.71$, respectively (DelValls et al. 1998; Yongming et al. 2006).

Hierarchical cluster analysis was used in this study. By using this method, the standardization of variables is performed automatically before computing proximities. Cluster analysis was applied to standardized data using the "Within-groups linkage" method, with Pearson 


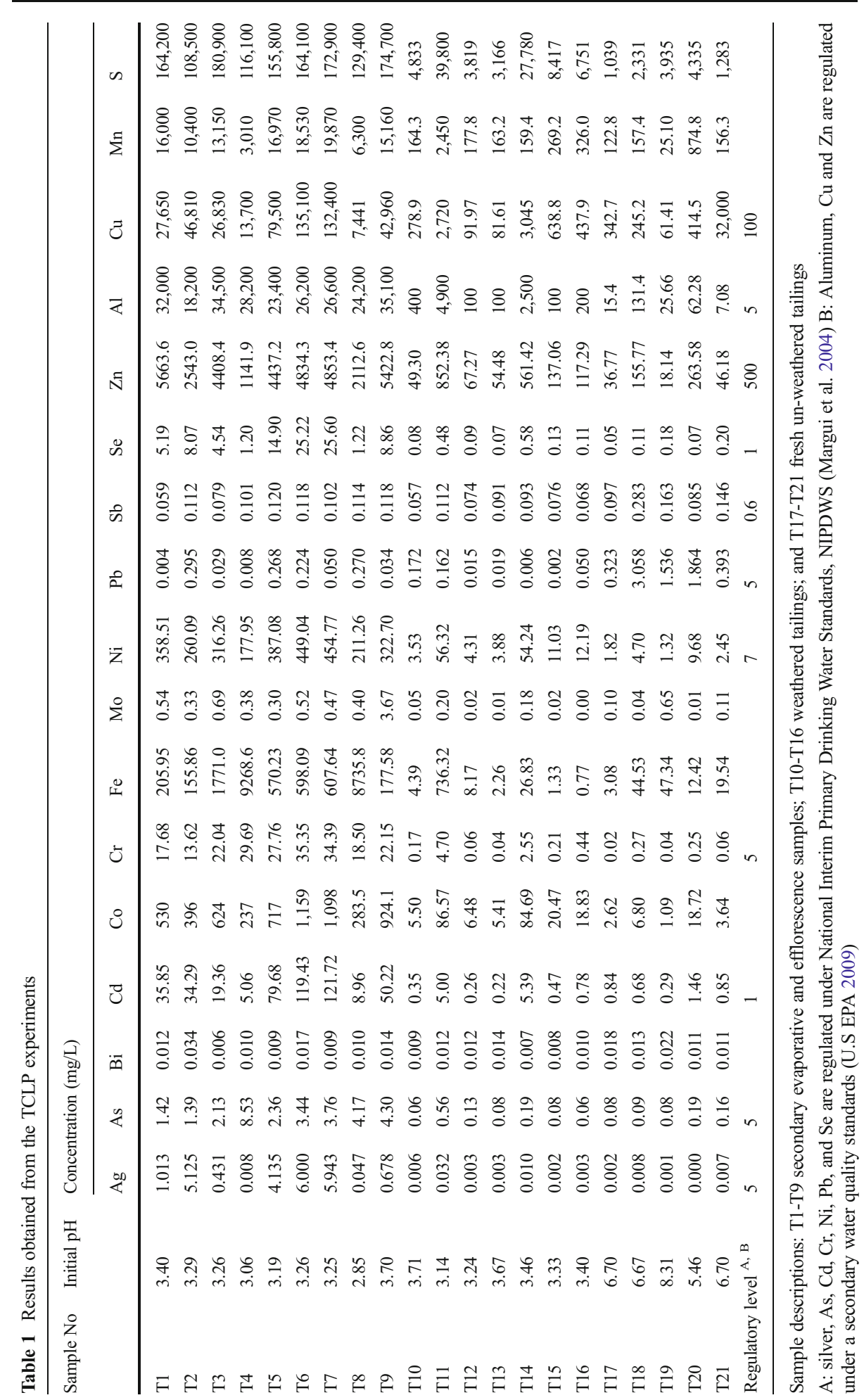


correlation as the criterion for forming clusters of elements (or variables). The SPSS software version 19 was used to perform the multivariate methods.

\section{Results and Discussion}

As noted earlier, samples were collected from different parts of the Sarcheshmeh tailings impoundment to evaluate elements leachability and mobility during the weathering of tailings. Table 1 shows the results obtained from TCLP experiments for target trace elements (Al, As, $\mathrm{Ag}, \mathrm{Bi}, \mathrm{Cd}, \mathrm{Co}, \mathrm{Cr}, \mathrm{Cu}, \mathrm{Fe}, \mathrm{Mn}, \mathrm{Mo}, \mathrm{Ni}, \mathrm{Pb}, \mathrm{S}, \mathrm{Sb}$, Se, and $\mathrm{Zn}$ ). The mean concentrations of trace elements in the TCLP results were compared with the mean total concentration of these elements (multi-acid digestion, $\mathrm{HCl}+\mathrm{HNO}_{3}+\mathrm{HF}+$ boric acid solution). The results for three groups of samples including fresh and weathered tailings and also secondary evaporative and efflorescence phases are shown in Fig. 4. A remarkable difference is observed in the correlation between total and leachable fractions of trace elements in the different group of samples. The correlation coefficients $-\mathrm{R}^{2}$ between TCLP results and total concentrations in the fresh tailings, weathered tailings and evaporative and efflorescence samples are $0.55,0.67$ and 0.95 , respectively. The reasons for the different geochemical behavior of trace elements in different types of tailings are discussed in the following sections.

\subsection{Fresh Tailings}

The results from TCLP experiments showed that the leachable fraction of most of trace elements such as $\mathrm{Ag}, \mathrm{Al}, \mathrm{As}, \mathrm{Bi}, \mathrm{Co}, \mathrm{Cr}, \mathrm{Se}, \mathrm{Sb}, \mathrm{Mo}, \mathrm{Zn}, \mathrm{Mn}$, and $\mathrm{Cu}$ leached from the fresh tailings comprised a small percentage of their total concentrations (Fig. 4a). Fresh tailings are the primary source of trace elements. Sarcheshmeh tailings are mainly composed of quartz (42\%), albite (9\%), sericite $(24 \%)$, chlorite $(11 \%)$, orthoclase $(8.3 \%)$, and pyrite $(7.5 \%)$ (Khorasanipour et al. 2011). Generally, most of trace elements in sulfidic mine wastes tailings are associated with the sulfide minerals, especially pyrite. Pyrite is the most abundant sulfide mineral in the Sarcheshmeh mine tailings and comprise about $7.5 \%$ of tailings (Khorasanipour et al. 2011). The iron sulfide, pyrite, is strongly associated with many trace metals like As, Bi, $\mathrm{Cd}, \mathrm{Co}, \mathrm{Cu}, \mathrm{Ga}, \mathrm{In}, \mathrm{Hg}, \mathrm{Mo}, \mathrm{Pb}, \mathrm{Re}, \mathrm{Sb}, \mathrm{Se}, \mathrm{Tn}, \mathrm{Te}$, and Zn (Spears et al. 1994). Chalcopyrite, the most important ore mineral in Cu-porphyry deposits, also can host minor and trace metals, such as $\mathrm{Ag}, \mathrm{As}, \mathrm{Bi}, \mathrm{Cd}, \mathrm{Co}, \mathrm{Cr}, \mathrm{In}, \mathrm{Mn}, \mathrm{Mo}, \mathrm{Ni}, \mathrm{Pb}, \mathrm{Sb}, \mathrm{Se}, \mathrm{Sn}, \mathrm{Ti}, \mathrm{V}$, and $\mathrm{Zn}$ in the form of cation substitutions (Vaughan and Craig 1978). Sulfide minerals in the fresh tailings samples are not oxidized, and therefore, their associated trace elements are mainly in the form of nonleachable fraction.

\subsection{Weathered Tailings}

The concentrations of $\mathrm{Cd}, \mathrm{Co}, \mathrm{Cu}, \mathrm{Mn}, \mathrm{Ni}, \mathrm{S}$, and $\mathrm{Zn}$ are increased in the TCLP results of weathered tailings (Fig. 4b). In spite of this fact, the concentration of $\mathrm{Ag}, \mathrm{Al}, \mathrm{As}, \mathrm{Bi}, \mathrm{Cr}, \mathrm{Fe}$, $\mathrm{Mo}, \mathrm{Pb}, \mathrm{Sb}$, and $\mathrm{Se}$ in TCLP leachates still remains much lower than their total concentrations. Tailing wastes become chemically unstable when exposed to an oxidizing environment, but the geochemical behavior of trace elements during the weathering and oxidation reactions, and subsequent acidic conditions, are considerably different. For example, the divalent cations are usually mobile under acidic conditions, while oxy-anions like Mo (V, VI) and As (V) show increasing adsorption to Fe (III) oxy-hydroxides with decreasing $\mathrm{pH}$ (Dzombak and Morel 1990; Dold and Fontboté 2001; Khorasanipour et al. 2012). This relationship is reflected by 

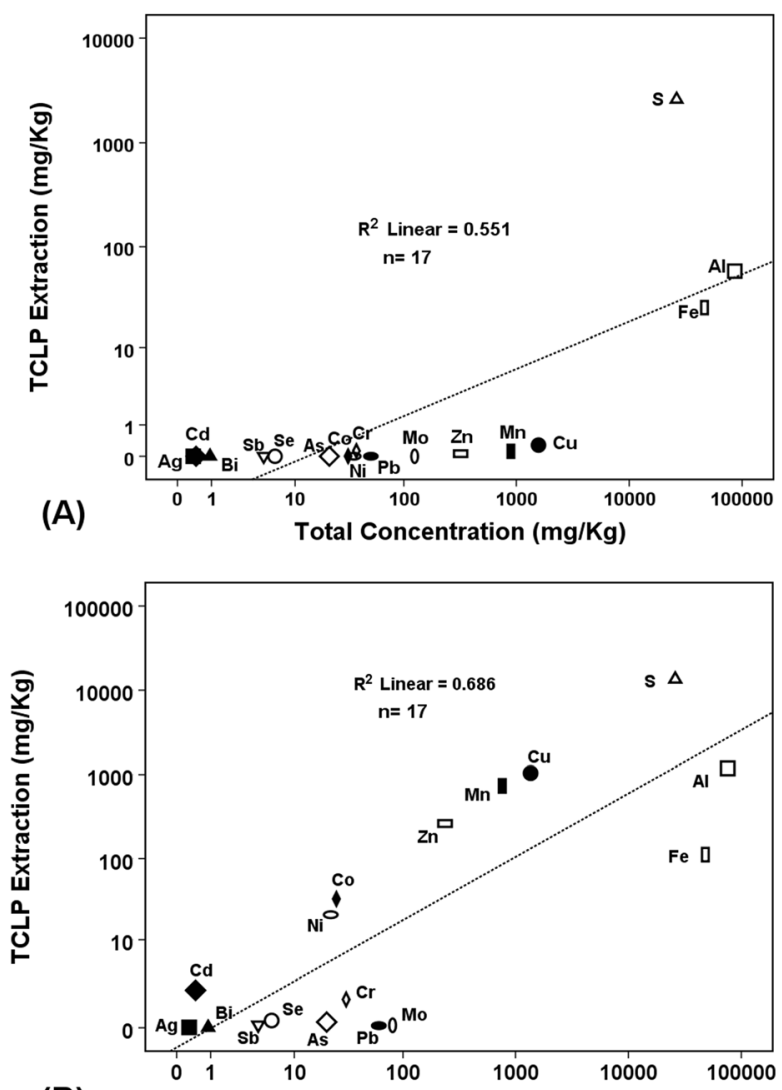

(B)

Total Concentration $(\mathrm{mg} / \mathrm{Kg})$

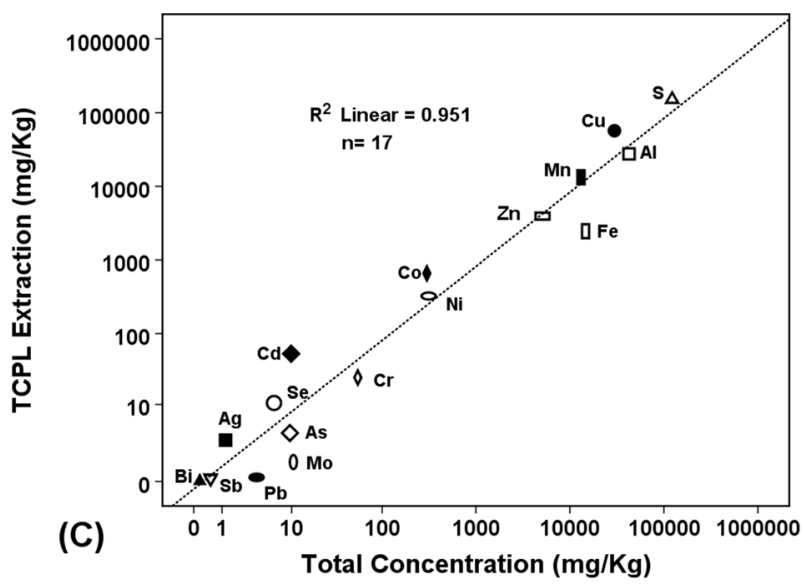

Fig. 4 The TCLP results versus the total concentrations of target trace elements in a fresh tailings, $\mathbf{b}$ weathered tailings and $\mathbf{c}$ evaporative and effloresce samples

the increased As concentration in Fe (III) oxy-hydroxides fraction in the oxidation zone of tailings (Dold and Fontboté 2001). Kelepertzis et al. (2012) also noted that the low Pb level as 
soluble fraction in the oxidation zone is related to the adsorption onto suspended and colloidal particles of hydrous ferric oxides. It is notable that, adsorption/desorption of trace elements is a selective process. For example, $\mathrm{As}$ and $\mathrm{Pb}$ are the most effectively adsorbed metal at acidic $\mathrm{pH}$ values, whereas $\mathrm{Zn}, \mathrm{Cd}$, and $\mathrm{Ni}$ are adsorbed at near neutral $\mathrm{pH}$ values (Plumlee 1999). By contrast, Mo is mobile up to $3.9 \mathrm{mg} / \mathrm{L}$ (Smuda et al. 2008) or up to $2.55 \mathrm{mg} / \mathrm{L}$ (Khorasanipour and Eslami 2014) in alkaline tailings waters.

The low concentration of $\mathrm{Ag}, \mathrm{Al}, \mathrm{As}, \mathrm{Bi}, \mathrm{Cr}, \mathrm{Fe}, \mathrm{Mo}, \mathrm{Pb}, \mathrm{Sb}$, and $\mathrm{Se}$ in the TCLP results of weathered tailings is due to the one of the following reasons:

1- The natural adsorption by adsorptive agents such as Fe-oxy-hydroxides that retain trace elements such as $\mathrm{As}, \mathrm{Pb}, \mathrm{Bi}$ and $\mathrm{Mo}$ in the solid form;

2- The movement of the released trace elements ( $\mathrm{Ag}, \mathrm{Al}, \mathrm{Cr}, \mathrm{Se}$ and $\mathrm{Sb}$ ) from weathering zone and concentrate in the surface evaporative layer.

The Sarcheshmeh tailings impoundment is located in a climate where evaporation exceeds the precipitation. In this climate regime, the water-flow direction changes to upward migration via the capillary force, and therefore, mobilized elements are transported to the top of the weathered tailings. This geochemical condition is same as the El Teniente and El Salvador porphyry copper tailings (Dold and Fontboté 2001).

The primary mineral assemblage was subjected to weathering and oxidation reactions in the upper oxidation zone of the tailings. In addition to the well-established pyrite oxidation reactions, chemical weathering of silicate minerals, such as albite and orthoclase, can consume hydrogen ions and release their elements $(\mathrm{Ca}, \mathrm{Na}, \mathrm{K}, \mathrm{Mg}, \mathrm{Mn}$, or $\mathrm{Fe})$ through incongruent (Eq. 2) or congruent weathering (Eq. 3) (Lottermoser 2003).

$$
\begin{aligned}
& 2 \mathrm{MeAlSiO}_{4(\mathrm{~s})}+2 \mathrm{H}^{+}{ }_{(\mathrm{aq})}+\mathrm{H}_{2} \mathrm{O} \rightarrow \mathrm{Me}^{\mathrm{x}+}{ }_{(\mathrm{aq})}+\mathrm{Al}_{2} \mathrm{Si}_{2} \mathrm{O}_{5}(\mathrm{OH})_{4(\mathrm{~s})} \\
& \mathrm{MeAlSiO}_{4(\mathrm{~s})}+\mathrm{H}^{+}{ }_{(\mathrm{aq})}+3 \mathrm{H}_{2} \mathrm{O} \rightarrow \mathrm{Me}^{\mathrm{x}+}{ }_{(\mathrm{aq})}+\mathrm{Al}^{3+}{ }_{(\mathrm{aq})}+\mathrm{H}_{4} \mathrm{SiO}_{4(\mathrm{aq})}+3 \mathrm{OH}^{-}{ }_{(\mathrm{aq})}
\end{aligned}
$$

where $\mathrm{Me}=\mathrm{Ca}, \mathrm{Na}, \mathrm{K}, \mathrm{Mg}, \mathrm{Mn}$, or Fe.

\subsection{Secondary Evaporative and Efflorescence Phases}

The TCLP results show that most of hazardous trace elements such as $\mathrm{Ag}, \mathrm{Al}, \mathrm{As}, \mathrm{Cd}, \mathrm{Ni}, \mathrm{S}$, $\mathrm{Se}, \mathrm{Co}, \mathrm{Cr}, \mathrm{Cu}, \mathrm{Fe}, \mathrm{Mn}$ and $\mathrm{Zn}$ are concentrated as leachable fraction in the surface evaporative minerals and efflorescence phases. The maximum correlation between TCLP results with the total concentration data was observed in this group of samples. Bismuth, $\mathrm{Mo}, \mathrm{Sb}$, and $\mathrm{Pb}$ are the only elements that have minimum concentration in the TCLP solutions of evaporative samples (Fig. 4c). Very high concentrations of $\mathrm{Al}\left(27,600 \mathrm{mg} \mathrm{L}^{-1}\right), \mathrm{Cu}\left(56,900 \mathrm{mg} \mathrm{L}^{-1}\right), \mathrm{Mn}$ $\left(13,260 \mathrm{mg} \mathrm{L}^{-1}\right), \mathrm{S}\left(151,800 \mathrm{mg} \mathrm{L}^{-1}\right)$, and $\mathrm{Zn}\left(3,935 \mathrm{mg} \mathrm{L}^{-1}\right)$ were observed in the TCLP results of the evaporative samples (mean values are presented). Evaporation of tailings water, especially from weathering zone, commonly leads to super-saturation, which controls the precipitation of mainly water soluble secondary sulfate minerals (Johnson et al. 2000; Dold and Fontboté 2001; McGregor and Blowes 2002). As suggested by other authors (e.g., Cravotta 1994; Lin 1997; Khorasanipour and Eslami 2014), formation and dissolution of secondary minerals, especially simple hydrous metal sulfates, can release metals, acidity, and sulfate into the water. This process is responsible for the low $\mathrm{pH}$ (from 2.5 to 4.1) and high 
concentrations of contaminants in the water samples associated with the highly weathered tailings (Khorasanipour and Eslami 2014).

According to Khorasanipour and Eslami (2014), dissolution of soluble secondary mineral phases, which are formed at and near the surface of the old weathered tailings, is responsible for the development of highly contaminated waters in short periods of time in the dry impoundment of the Sarchshmeh mine tailings. Fine grain size increases the water retention capacity and capillarity force of the tailings, resulting in higher mobilization of water to the surface and enrichment of bivalent cations, $\mathrm{Cl}^{-}$, and $\mathrm{SO}_{4}{ }^{-2}$ in water soluble phases. Significant upward mobilization of $\mathrm{Al}, \mathrm{Na}, \mathrm{Cl}, \mathrm{Cd}, \mathrm{Co}, \mathrm{Cr}, \mathrm{Cu}, \mathrm{Mg}, \mathrm{Mn}, \mathrm{Ni}, \mathrm{Se}, \mathrm{SO}_{4}{ }^{-2}$, and $\mathrm{Zn}$ takes place during the dry seasons in the Sarcheshmeh mine tailings (Khorasanipour and Eslami 2014). Upward migration is later superimposed on the general trend of downward mobilization during the rainy season. These hydro-geochemical and environmental important processes are similar to those has been reported in previous studies (Dold and Fontboté 2001; Wu et al. 2009; Zhao et al. 2012).

\subsection{Multivariate Statistical Descriptions}

Principal component analysis (PCA) and cluster analysis (CA), as the most important multivariate statistical methods, have been widely used to interpret the geochemical, hydrogeochemical and environmental data sets (Khorasanipour et al. 2012). These methods provide a further insight about the latent relationship between variables and/or samples.

According to the Varimax rotated principal components analysis, four factors have eigenvectors higher than Kaiser Criterion (1960) (Table 2). The $90 \%$ of the total variance of the TCLP data is explained by these four principal components. Factor 1 , with about $50 \%$ of the total variance, has significant positive loadings of $\mathrm{Al}, \mathrm{Cd}, \mathrm{Cr}, \mathrm{Cu}, \mathrm{Mn}, \mathrm{Mo}, \mathrm{Ni}, \mathrm{S}, \mathrm{Se}$, and $\mathrm{Zn}$. According to the TCLP results, these elements (except Mo) were highly mobile and concentrated in the surface evaporative layer of tailings. In the TCLP results, the leachable fraction of Mowas also increased from fresh tailings to the weathered tailings and surface evaporative samples as same as other elements such as $\mathrm{Cu}, \mathrm{S}$ and $\mathrm{Zn}$, but in all cases the leachable fraction of Mo comprised very small fraction of its total concentration.

The second factor of PCA contains $17 \%$ of the total variance of data. Iron, As and Sn are elements that have significant loadings in this factor. The role of iron in the adsorption of hazardous trace elements, like As, especially in weathered tailings, is obvious. Component 3 that accounted for $12.7 \%$ of the variance in the rotated PCA matrix is characterized by high loadings of $\mathrm{Ag}$ and $\mathrm{Bi}$. Also, $\mathrm{Pb}$ and $\mathrm{Sb}$ are situated in the component 4 of PCA that accounted for $10.7 \%$ of the total variance. Except of Ag, which was increased in the TCLP results of evaporative samples, in other cases elements in these two latest factors of PCA have low concentration in the TCLP experiments. The relationships between different trace elements can be made easier to understand by mapping the variable loadings. Figure 5 represents the threedimensional plots of the rotated component matrices of the TCLP data set. In this figure, a clear distinction is observed between elements with the same geochemical behavior. The most leachable trace elements ( $\mathrm{Al}, \mathrm{Cd}, \mathrm{Cr}, \mathrm{Cu}, \mathrm{Mn}, \mathrm{Mo}, \mathrm{Ni}, \mathrm{S}, \mathrm{Se}$, and $\mathrm{Zn}$ ) are well separated from trace elements with low leachability in the 3-D PCA plot.

Figure 6 shows the results of the hierarchical cluster analysis (CA). Three distinct groups of elements were identified according to the cluster analysis. The main results are as follows:

1- Elements with high leachability and mobility: According to the degree of association, this group of elements is divided into the several subgroups including: 
Table 2 Component matrices and total variance explained by applying the Varimax rotated PCA method to the TCLP results. Factor loadings lower than 0.5 are removed

\begin{tabular}{|c|c|c|c|c|c|}
\hline \multirow[t]{2}{*}{ Variables } & \multicolumn{4}{|c|}{ Rotated component matrix } & \multirow[t]{2}{*}{ Communalities } \\
\hline & $\mathrm{F} 1$ & $\mathrm{~F} 2$ & $\mathrm{~F} 3$ & $\mathrm{~F} 4$ & \\
\hline $\mathrm{Al}$ & 0.87 & & & & 0.99 \\
\hline $\mathrm{Cd}$ & 0.87 & & & & 0.98 \\
\hline Co & 0.98 & & & & 0.98 \\
\hline $\mathrm{Cr}$ & 0.78 & & & & 0.99 \\
\hline $\mathrm{Cu}$ & 0.83 & & & & 0.98 \\
\hline $\mathrm{Mn}$ & 0.97 & & & & 0.97 \\
\hline Mo & 0.69 & & & & 0.98 \\
\hline $\mathrm{Ni}$ & 0.93 & & & & 0.98 \\
\hline $\mathrm{S}$ & 0.91 & & & & 0.97 \\
\hline $\mathrm{Se}$ & 0.85 & & & & 0.98 \\
\hline $\mathrm{Zn}$ & 0.98 & & & & 0.97 \\
\hline As & & 0.87 & & & 0.97 \\
\hline $\mathrm{Fe}$ & & 0.95 & & & 0.75 \\
\hline $\mathrm{Sn}$ & & 0.80 & & & 0.95 \\
\hline $\mathrm{Ag}$ & & & 0.85 & & 0.95 \\
\hline $\mathrm{Bi}$ & & & 0.71 & & 0.87 \\
\hline $\mathrm{Pb}$ & & & & 0.90 & 0.92 \\
\hline $\mathrm{Sb}$ & & & & 0.95 & 0.89 \\
\hline Initial Eigenvalues & 9.00 & 3.05 & 2.29 & 1.93 & \\
\hline Percent of variance & 49.99 & 16.94 & 12.73 & 10.73 & \\
\hline Cumulative percent & 49.99 & 66.93 & 79.66 & 90.39 & \\
\hline
\end{tabular}

Factor loadings lower than 0.5 are removed

Extraction method: principal component analysis. Rotation method: varimax with Kaiser normalization. Rotation converged in five iterations
I. $\mathrm{Cu}=\mathrm{Se}=\mathrm{Cd}>\mathrm{Ag}$
II. $\mathrm{Mn}=\mathrm{Zn}=\mathrm{Ni}=\mathrm{Co}$
III. $\mathrm{Al}=\mathrm{S}>\mathrm{Co}$

2- $\mathrm{As}=\mathrm{Fe}>>\mathrm{Sn}$. This elemental association is same as the second component of the PCA.

3- $\mathrm{Pb}$ and $\mathrm{Sb}$ have a strong association in this group similar to the fourth component of PCA. The association of $\mathrm{Bi}$ with $\mathrm{Pb}$ and $\mathrm{Sb}$ is also very weak in the higher order of cluster analysis.

According to the cluster analysis method, it is possible to classify target trace elements in more homogenous groups of elemental associations. These results strongly confirm PCA results.

\subsection{Comparison With the Regulatory Levels}

A solid waste exhibits the characteristic of toxicity if the concentration of any target contaminant in the TCLP extract is greater than or equal to the respective recommended US EPA 


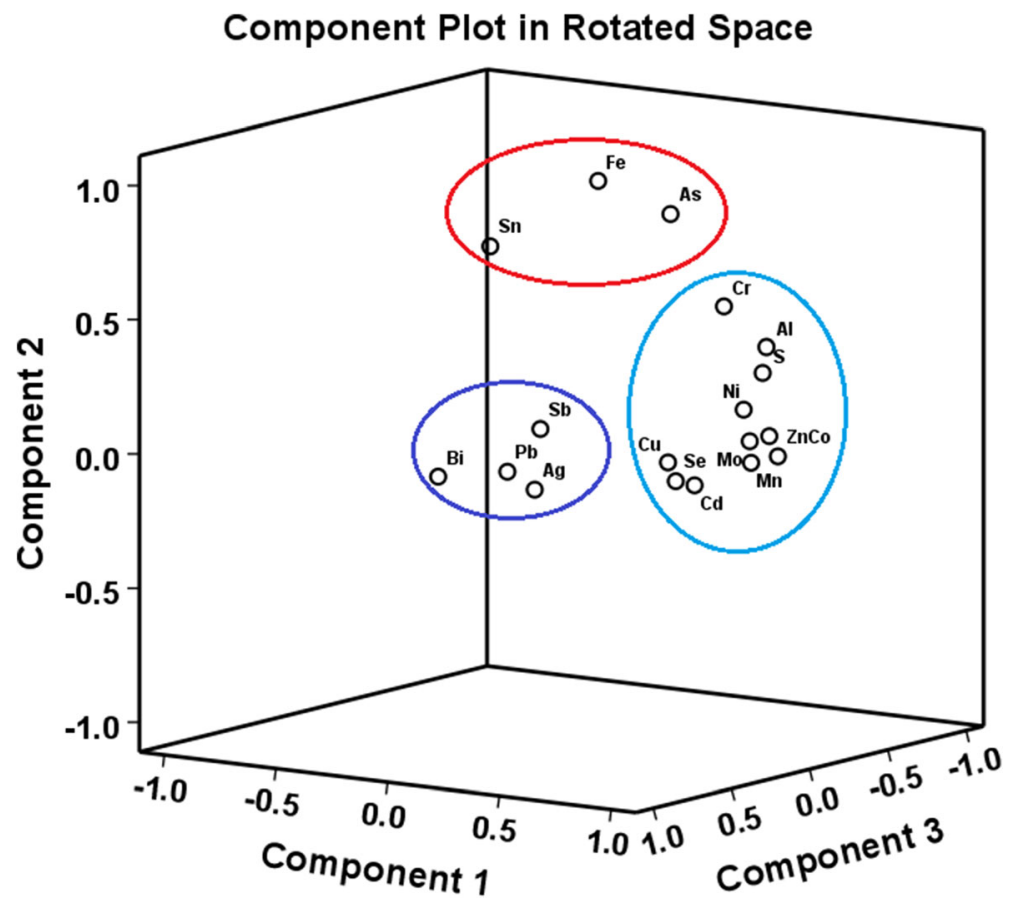

Fig. 5 The PCA results in the three dimensional space: plot of loadings of the first three principal components of varimax rotated $\mathrm{PCA}$

regulatory limit value (Margui et al. 2004). The regulatory levels or standard values typically are based on 100 times the National Interim Primary Drinking Water Standards for metals, NIPDWS (Margui et al. 2004). These regulatory values are $5 \mathrm{mg} / \mathrm{L}$ for $\mathrm{As}, \mathrm{Pb}, \mathrm{Ag}$ and $\mathrm{Cr}$, $1 \mathrm{mg} / \mathrm{L}$ for $\mathrm{Cd}$ and $\mathrm{Se}$, and $7 \mathrm{mg} / \mathrm{L}$ for Ni (Eckert and Guo 1998). Given that TCLP regulatory

Dendrogram using Average Linkage (Between Groups)

Rescaled Distance Cluster Combine

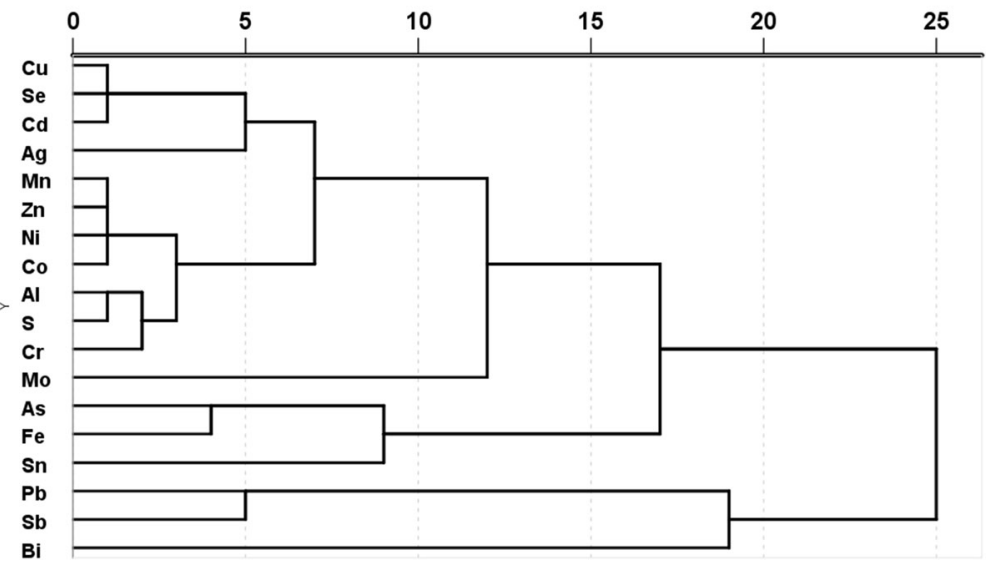

Fig. 6 Hierarchical cluster analysis results of TCLP data set by the use of "Between-groups linkage" method. Similarities have been calculated from the Pearson correlation 
limits exist for only nine metals, in this study, one-hundred times the secondary drinking water standards of $\mathrm{Cu}, \mathrm{Al}, \mathrm{Sb}$ and $\mathrm{Zn}$, defined by the US EPA (2009), were also used for evaluation of TCLP results. These values are $100 \mathrm{mg} / \mathrm{L}$ for $\mathrm{Cu}, 5 \mathrm{mg} / \mathrm{L}$ for $\mathrm{Al}, 0.6 \mathrm{mg} / \mathrm{L}$ for $\mathrm{Sb}$, and $500 \mathrm{mg} / \mathrm{L}$ for $\mathrm{Zn}$. The TCLP results were compared to the regulatory levels by using the following Eq. (4):

$$
\mathrm{EF}=\frac{\text { Concentration in TCLP experiments }}{\text { Regulatory level }}
$$

where $\mathrm{EF}$ is the enrichment factor. The results showed that the concentrations of $\mathrm{Ag}, \mathrm{As}, \mathrm{Pb}$, and $\mathrm{Sb}$ leached from different samples after $18 \mathrm{~h}$ extraction period are mainly below the recommended regulatory levels. On the other hand, the concentrations of $\mathrm{Al}, \mathrm{Cu}, \mathrm{Cd}, \mathrm{Cr}, \mathrm{Ni}$, $\mathrm{Se}$ and $\mathrm{Zn}$ in TCLP results are much higher than the regulatory levels. Among the investigated toxic metals the maximum enrichments were observed for $\mathrm{Al}$ and $\mathrm{Cu}$, followed by $\mathrm{Ni}>\mathrm{Cd}>\mathrm{Zn}>\mathrm{Se}>\mathrm{Cr}$. Figure 7 shows the order of trace elements enrichment based on the median values. The enrichment values for trace elements in the three groups of investigated samples (fresh and weathered tailings and evaporative phases) are remarkably different. For example, the concentration of $\mathrm{Al}, \mathrm{Cu}, \mathrm{Cd}, \mathrm{Ni}, \mathrm{Se}$, and $\mathrm{Zn}$ in the TCLP results of fresh and weathered tailings are lower than their recommended regulatory levels. On the contrary, the results obtained for these elements in evaporative and the efflorescence samples exceed the criteria of 100 times the US EPA regulatory levels. These results clearly show how a very hazardous waste material is made from non-hazardous fresh tailings. The weathering and associated processes together with the semiarid climate conditions are responsible for the release and transport of hazardous trace elements from fresh tailings to the surface evaporative layer on the top of old weathered tailings. The correlation matrix between enrichment values also shows that the most leachable and potentially contaminant trace elements ( $\mathrm{Al}, \mathrm{Cu}, \mathrm{Ni}, \mathrm{Cd}$, $\mathrm{Zn}$, Se, and $\mathrm{Cr}$ ) are positively correlated with each other and strongly concentrated in the efflorescence salts and secondary evaporative minerals (Fig. 8).

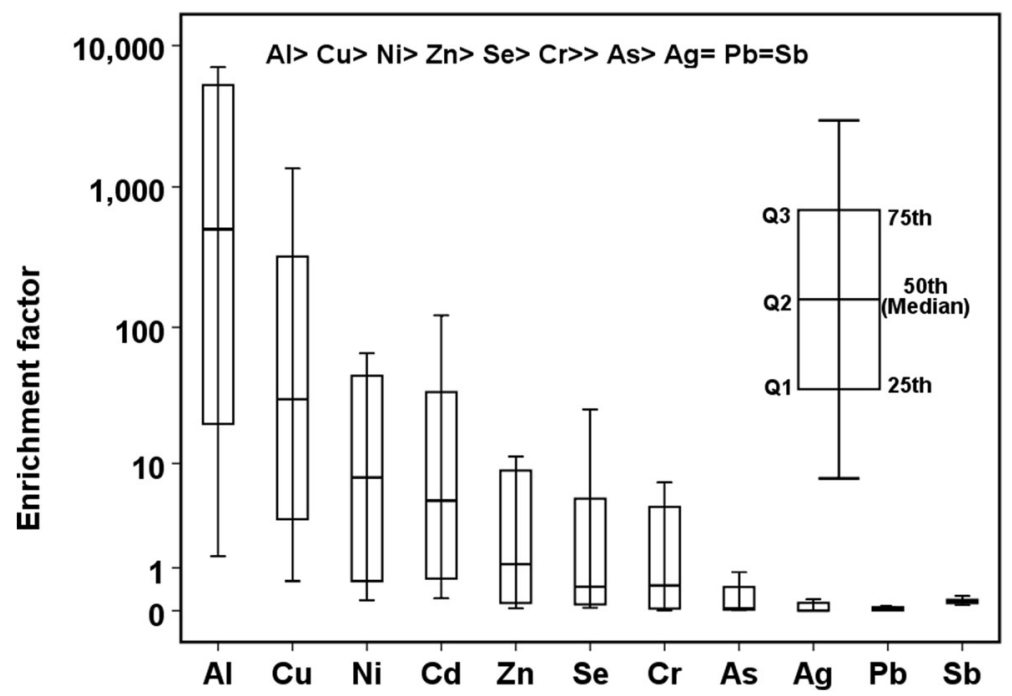

Fig. 7 Box plot showing the order of enrichment for $\mathrm{Cu}, \mathrm{Cd}, \mathrm{Se}, \mathrm{Al}, \mathrm{Ni}, \mathrm{As}$ and $\mathrm{Ag}$ in the TCLP results compared with the U.S. EPA regulatory revels 


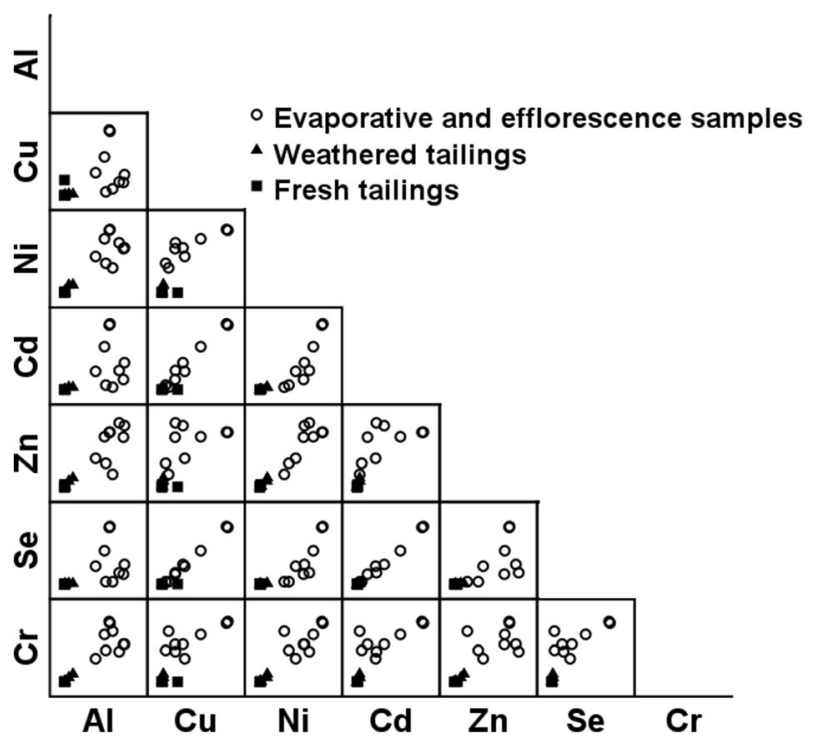

Fig. 8 The correlation matrix between enrichment values of most of leachable and highly mobile trace elements

Weathering and oxidation of fresh tailings lead to the trace metal contamination in the Sarcheshmeh tailings impoundment. Environmental management of mine tailings for short and long periods of times must be done taking into consideration the several site specific conditions such as: (1) tailings impoundment is situated in semiarid climatic condition with high evaporation rates of water in dry seasons; (2) due to the fine grain size of tailings uncovered tailings are susceptible to severe water and wind erosion, which creates pollution for air, soil and water; (3) multi-elemental contamination is observed in tailings waste; (4) the dam is not at the final stage and in the future the old weathered tailings will be covered by new fresh tailings; (5) most of tailings water is recycled from the tailings impoundment to the Sarcheshmeh copper complex for further industrial use.

\section{Conclusions}

Sarcheshmeh mine tailings are dried quickly and exposed to the weathering and oxidation reactions due to the semiarid climate conditions. The supernatant waters are recycled and reused for further industrial purposes. According to the TCLP experiments, remarkable differences were observed between the leachability and mobility potential of different trace elements during the weathering and oxidation of fresh tailings. The leachable fraction of potentially hazardous trace elements was increased from weathered tailings to the evaporative and efflorescence phases. A remarkable increase was observed in the leachable fraction of $\mathrm{Ag}$, $\mathrm{Al}, \mathrm{As}, \mathrm{Cd}, \mathrm{Ni}, \mathrm{S}, \mathrm{Se}, \mathrm{Co}, \mathrm{Cr}, \mathrm{Cu}, \mathrm{Mn}$ and $\mathrm{Zn}$ in the surface evaporative layer of old weathered tailings.

The concentrations of $\mathrm{Al}, \mathrm{Cu}, \mathrm{Cd}, \mathrm{Ni}, \mathrm{Se}$ and $\mathrm{Zn}$ in the TCLP results of the evaporative and efflorescence samples are much higher than the recommended regulatory levels and must be classified as hazardous materials. These hazardous waste materials are formed as a result of weathering and oxidation of fresh tailings. High evaporation rate together with the capillary forces are responsible for the movement of released elements 
to the surface and formation of secondary evaporative phases on the top of weathered tailing in dried impoundments. The contamination potential of trace elements in the Sarcheshmeh mine tailings is controlled by geochemical and climatological conditions. Both of these factors are of crucial importance for environmental management and remediation actions of tailings.

Acknowledgments The authors would like to thank the cooperation of the Research and Development Division of the Sarcheshmeh Copper Complex for financial support and access to sampling. The comprehensive reviews of an earlier version of the manuscript by the editor and four anonymous reviewers of the Journal Environmental Processes are greatly appreciated.

\section{References}

Akcil A, Koldas S (2006) Acid mine drainage (AMD): causes, treatment and case studies. J Clean Prod 14:11391145

Atapour H, Aftabi A (2007) The geochemistry of gossans associated with Sarcheshmeh porphyry copper deposit, Rafsanjan, Kerman, Iran: implications for exploration and the environment. J Geochem Explor 93:47-65

Bayless ER, Olyphant GA (1993) Acid-generating salts and their relationship to the chemistry of groundwater and storm runoff at an abandoned minesite in southwestern Indiana, U.S.A. J Contam Hydrol 12:313-328

Berger BR, Ayuso RA, Wynn JC, Seal RR (2008) Preliminary model of porphyry copper deposits: U.S Geological Survey Open-File Report, 321, 55 p

Blowes DW, Reardon EJ, Cherry JA, Jambor JL (1991) The formation and potential importance of cemented layers in inactive sulfide mine tailings. Geochim Cosmochim Acta 55:965-978

Chang EE, Chiang PC, Lu PH, Ko YW (2001) Comparisons of metal leachability for various wastes by extraction and leaching methods. Chemosphere 45:91-99

Coggans CL, Blowes DW, Robertson WD, Jambor JL (1999) The hydrogeochemistry of nickel-mine tailing impoundments- Copper Cliff, Ontario. In: Filipek LH, Plumlee GS (eds), Environmental geochemistry of mineral deposits. Part B: Case studies and research topics. Society of Economic Geologists, Littleton (Reviews in economic geology, vol 6b, p 447-456

Cravotta CA (1994) Secondary iron-sulfate minerals as sources of sulfate and acidity. In: Alpers CN, Blowes DW (Eds.), Environmental Geochemistry of Sulfide oxidation, Am. Chem. Soc Symp Ser 550, p 345-364

DelValls TA, Forja JM, Gonzalez-Mazo E, Gomez-Parra A (1998) Determining contamination sources in marine sediments using multivariate analysis. Trend Anal Chem 17:181-192

Dimitrijevic MD (1973) Geology of Kerman region: Institute for geological and mining exploration and investigation of nuclear and other mineral raw material, Beograd-Yugoslavia, Iran Geol. Survey Rept $\mathrm{Yu} / 52$

Dold B, Fontboté L (2001) Element cycling and secondary mineralogy in porphyry copper tailings as function of climate, primary mineralogy, and mineral processing. J Geochem Explor 74:2-55

Dzombak DA, Morel FMM (1990) Surface complexation modeling-hydrous ferric oxides. Wiley, New York

Eckert JJO, Guo Q (1998) Heavy metals in cement and cement kiln dust from kilns co-fired with hazardous waste-derived fuel: application of EPA leaching and acid-digestion procedures. J Hazard Mater 59:55-93

Emmerson RHC, O'Reilly-Wiese SB, Macleod CL, Lester JN (1997) A multivariate assessment of metal distribution in inter-tidal sediments of the Blackwater Estuary, UK. Mar Pollut Bull 34:960-968

Filgueiras AV, Lavilla I, Bendicho C (2002) Chemical sequential extraction for metal partitioning in environmental solid samples. J Environ Monit 4:823-857

Gleyzes C, Tellier S, Astruc M (2002) Fractionation studies of trace elements in contaminated soils and sediments: a review of sequential extraction procedures. Trends Anal Chem 21:451-466

Grangeia C, Ávila P, Matias M, Ferreira da Silva E (2011) Mine tailings integrated investigations: the case of Rio tailings (Panasqueira Mine, Central Portugal). Eng Geol 123:359-372

Halim CE, Scott JA, Amala R, Short SA, Beydoun D, Low G, Cattle J (2005) Evaluating the applicability of regulatory leaching tests for assessing the hazards of $\mathrm{Pb}$-contaminated soils. J Hazard Mater 120:101-111

Hammarstrom JM, Seal RR, Meier AL, Kornfeld JM (2005) Secondary sulfate minerals associated with acid drainage in the eastern US: recycling of metals and acidity in surficial environments. Chem Geol 215:407431

Hlavay J, Prohaska T, Weisz M, Wenzel WW, Stingeder GJ (2004) Determination of trace elements bound to soils and sediment fractions. IUPAC Tech. Rep. Pure Appl Chem 76:415-442 
Johnson RH, Blowes DW, Robertson WD, Jambor JL (2000) The hydrogeochemistry of the Nickel Rim mine tailings impoundment, Sudbury, Ontario. J Contam Hydrol 141:49-80

Kaiser HF (1960) The application of electronic computers to factor analysis. Educ Psychol Meas 20:141-151

Kelepertzis E, Argyraki A, Daftsis E (2012) Geochemical signature of surface water and stream sediments of a mineralized drainage basin at NE Chalkidiki, Greece: a pre-mining survey. J Geochem Explor 114:70-81

Khorasanipour M, Eslami A (2014) Hydrogeochemistry and contamination of trace elements in Cu-porphyry mine tailings; a case study from the Sarcheshmeh mine, SE Iran. Mine Water Environ. doi:10.1007/s10230014-0272-X

Khorasanipour M, Tangestani MH, Naseh R, Hajmohammadi H (2011) Hydrochemistry, mineralogy and chemical fractionation of mine and processing wastes associated with porphyry copper mines: a case study from the Sarcheshmeh mine, SE Iran. Appl Geochem 26:714-730

Khorasanipour M, Tangestani MH, Naseh R (2012) Application of multivariate statistical methods to indicate the origin and geochemical behavior of potentially hazardous elements in sediment around the Sarcheshmeh copper mine, SE Iran. Environ Earth Sci 66:589-605

Lin Z (1997) Mineralogical and chemical characterization of wastes from the Sulfuric acid industry in Falun, Sweden. Environ Geol 39:152-162

Lottermoser BG (2003) Mine waste: characterization, treatment and environmental impacts. Springer press, Berlin

Margui E, Salvadó V, Queralt I, Hidalgo M (2004) Comparison of three-stage sequential extraction and toxicity characteristic leaching tests to evaluate metal mobility in mining wastes. Anal Chim Acta 524:151-159

McGregor RG, Blowes DW (2002) The physical, chemical and mineralogical properties of three cemented layers within sulfide-bearing mine tailings. J Geochem Explor 76:195-207

Olyphant GA, Bayless GR, Harper D (1991) Seasonal and weather-related controls on solute concentrations and acid drainage from a pyritic coal-refuse deposit in southwestern Indiana, USA. J Contam Hydrol 7:219-236

Plumlee GS (1999) The environmental geology of mineral deposits. In: Plumlee GS, Logsdon MJ (Eds.), The Environmental Geochemistry of Mineral Deposits Part A. Processes, Techniques and Health Issues. Reviews in Economic Geology, Society of Economic, Geologist, Inc., Colorado, vol. 6 A, p 71-116

Redwan M, Rammlmair D (2012) Influence of climate, mineralogy and mineral processing on the weathering behaviour within two, low-sulfide, high-carbonate, gold mine tailings in the Eastern Desert of Egypt. Environ Earth Sci 65:2179-2193

Saxena M, Dhimole LK (2006) Utilization and value addition of copper tailing as an extender for development of paints. J Hazard Mater 129:50-57

Shahabpour J, Kramers JD (1987) Lead isotope data from the Sarcheshmeh porphyry copper deposit, Iran. Miner Deposita 22:275-281

Sima M, Dold B, Frei L, Senila M, Balteanu D, Zobrist J (2011) Sulfide oxidation and acid mine drainage formation within two active tailings impoundments in the Golden Quadrangle of the Apuseni Mountains, Romania. J Hazard Mater 189:624-639

Smuda J, Dold B, Spangenberg JA, Pfeifer HR (2008) Geochemistry and stable isotope composition of fresh alkaline porphyry copper tailings: implications on sources and mobility of elements during transport and early stages of deposition. Chem Geol 256:62-76

Spears DA, Tarazona MRM, Lee S (1994) Pyrite in UK coals: its environmental significance. Fuel 37:1051-1055

U.S Environmental Protection Agency (1986) Hazardous waste management system; land disposal restriction. Appendix I to Part 268: toxicity characteristic leaching procedure (TCLP), 51 (216). Federal Register, pp. 40643-40654

U.S Environmental Protection Agency (1994) Method 1311, Toxicity Characteristic Leaching Procedure, Test Methods for Evaluating Solid Wastes Physical/Chemical Methods, United States Environmental Protection Agency

U.S Environmental Protection Agency (2009) National primary and secondary regulations. Available at: http:// www.epa.gov/safewater

Vaughan DJ, Craig JR (1978) Mineral chemistry of metal sulfides. Cambridge Earth Science Series, Cambridge University Press, Cambridge

Webster R (2001) Statistics to support soil research and their presentation. Eur J Soil Sci 52:331-340

Wu P, Tang CY, Liu CQ, Zhu LJ, Pei TQ, Feng LJ (2009) Geochemical distribution and removal of As, Fe, Mn and $\mathrm{Al}$ in a surface water system affected by acid mine drainage at a coalfield in southwestern China. Environ Geol 57(7):1457-1467

Yongming H, Peixuan D, Junji C, Posmentier ES (2006) Multivariate analysis of heavy metal contamination in urban dusts of Xi'an, Central China. Sci Total Environ 355:176-186

Zhang C (2007) Fundamentals of environmental sampling and analysis. Published by John Wiley \& Sons, Inc, $457 \mathrm{p}$

Zhao H, Xia B, Qin J, Zhang J (2012) Hydrogeochemical and mineralogical characteristics related to heavy metal attenuation in a stream polluted by acid mine drainage: a case study in Dabaoshan Mine, China. J Environ Sci 24(6):979-989 